\title{
Political Rioting: A Moral Assessment
}

On April 12, 2015, three Baltimore police officers arrested a 25-year-old African American named Freddie Gray, on the suspicion of possessing a switchblade knife. A video recording of the arrest shows Gray screaming in pain as he is being dragged into a police van. Sometime during the arrest Gray sustained a spinal cord injury. Four days later he died. ${ }^{1}$

Gray's funeral was held two weeks later at the Shiloh Baptist Church in Baltimore. In the afternoon of that day a crowd of young African Americans, coordinated through social media, gathered in front of the Mondawmin Shopping Mall in Northwest Baltimore. Police officers who were called to the area were met with chants of "Fuck the Police!" and "Don't Shoot!" Soon after, the crowd started throwing rocks, bricks and glass bottles. Nearby, a police car and some private vehicles were set on fire. A few streets away a CVS pharmacy was looted, and the hoses of a fire engine that arrived at the scene were slashed. The disorder continued for a few hours into the night. By the end of it, at least fifteen police officers were injured, and twenty-seven people were arrested. ${ }^{2}$

\footnotetext{
I would like to thank the following for their helpful comments and advice: Kimberley Brownlee, Candice Delmas, Cecile Fabre, Helen Frowe, Bob Goodin, Jeff Howard, Rob Jubb, George Klosko, David Lefkowitz, Roland Meeks, Ben Saunders, Rob Simpson, Zofia Stemplowska, Patrick Tomlin, Aart Vangalis and Albert Weale. Special thanks go to two reviewers of Philosophy and Public Affairs, for their detailed and constructive feedback. Particular thanks go to my colleague Emily McTernan with whom I had many invaluable discussions on the topic. Versions of this paper were presented to audiences at University London College, University College Dublin, The University of Oxford and the University of Reading. ${ }^{1}$ David Graham, "The Mysterious Death of Freddie Gray", The Atlantic 22/5/2015. 2 Julia Craven and Arthur Delaney, "How the Baltimore Chaos Started after Freddie Gray's Funeral", Huffington Post 28/4/2015.
} 
Similar scenes were repeated in the following nights across Baltimore. They were part of a wave of urban riots that swept over America between August 2014 and April 2015, triggered by incidents of police brutality against African American citizens. The US is not the only liberal democracy to have experienced widespread riots in recent years. Other examples include the 2005 French Banlieue riots, the 2011 English riots and the 2018 Paris riots.

What is the appropriate moral response to such episodes of public disorder? In political practice we find two common answers to this question. The first is that rioters are no different from common criminals who engage in similar levels of lawlessness and violence. This attitude was reflected, for example, in then UK Prime Minister David Cameron's dismissal of the 2011 riots as “common or garden thieving, robbing and looting", 3 and in Baltimore Police Commissioner Antony Batts's referral to the to the 2015 riots as "just criminal activity". ${ }^{4}$ The second answer is that rioters are morally worse than common criminals. This attitude was reflected, for example, in the harsher than usual legal penalties handed down to those involved in the 2011 English riots. According to a recent survey this sentiment is largely shared by the British public. ${ }^{5}$

This article examines the appropriateness of such responses to a specific type of rioting, which I call "political rioting". Political rioters resort to spontaneous,

\footnotetext{
${ }^{3}$ Hansard HC 11/8/ 2011. Col. 1075.

${ }^{4}$ Jon Swaine, Ben Jacobs, and Paul Lewis, "Baltimore Protests Turn into Riots as Mayor Declares State of Emergency “, The Guardian 28/4/2015. ${ }^{5}$ Julian V Roberts and Mike Hough, "Sentencing Riot-Related Offending: Where Do the Public Stand?", British Journal of Criminology 53, 2 (2013). Although the majorty of respondants found the sentences meted out by the courts in this instance to be overly harsh.
} 
disorganized, public collective violence in order to protest against and to defy their political order. As we shall see, pace common depictions of rioters as engaging in senseless violence, many riots in democratic states (the states I shall focus on) over recent decades were political in this sense. And yet, despite the relative salience of political riots in the real world, so far political philosophers have paid scant attention to them. The rich literature on civil disobedience defends the resort to illegal protest against serious injustices, but it typically limits itself to non-violent protest. Some literature on political obligations in unjust democracies touches upon riots. Tommie Shelby, for example, notes that under conditions of gross injustice "public unrest can seem to be the only power the Ghetto poor can yield collectively". ${ }^{6}$ But his brief comments do not amount to a fully-fledged moral assessment of political rioting. ${ }^{7}$

The goal of this paper is to develop such an assessment. To do that, I suggest we turn to recent literature on the permissibility of "defensive harm" - harm that is inflicted by an agent in order to avert an attack on them (or on others). ${ }^{8}$ Much of the literature on defensive harm examines it in the context of war - perhaps the most radical form of collective violence. Political riots are clearly different from war, in various senses. While wars involve the mass killings of soldiers and civilians, rioters typically inflict mostly damage to property, and some limited harm to persons. While wars are carried

\footnotetext{
${ }^{6}$ Tommie Shelby, Dark Ghettos: Injustice, Dissent, and Reform (Cambridge Mass.: Harvard University Press, 2016), 223-224.

7 Two other recent texts that comment on riots as a form of political protest are Candice Delmas, A Duty To Resist: When Disobedience Should be Uncivil (New York: Oxford University Press, 2018) and Juliet Hooker "Black Lives Matter and the Paradoxes of U.S. Black Politics: From Democratic Sacrifice to Democratic Repair" Political Theory 44, 4 (2016). Both offer arguments in defence of riots as a form of political protest, but their accounts are less detailed, and do not engage with the various objections and constraints I discuss here.

${ }^{8}$ David Rodin, "Justifying Harm", Ethics 122, 1 (2011), 74. Jeff McMahan, Killing in War (Oxford Oxford University Press, 2009), 8-9.
} 
out by military units operating under a single command structure, riots erupt spontaneously, and lack central command mechanisms. And while just combatants resort to war against an immanent attack by an enemy state, the rioters I shall focus on here resort to violence in response to mere socio-economic and political injustices: material deprivation, racial segregation and political and cultural marginalization.

But despite these important differences, political rioting remains a form of defensive harm, in the sense that those who resort to it do so in order to bring an end, or at least to ameliorate, their on-going unjust treatment at the hands of their state. It follows then that in determining the appropriate moral response to rioters, we ought to examine their actions in light of the various constraints offered by just war theorists. First, the necessity constraint, which requires that the harm inflicted on behalf of a just cause is the least harmful available means for doing so. Second, the success constraint, which requires that the resort to defensive harm will have a reasonable chance of successfully averting the attack. Third, the proportionality constraint, which requires that the defensive harm inflicted is proportionate to the harm it aims to avert. Current literature so far has not examined what these requirements tell us about the permissibility of political rioting, given its specific features and the political context in which political rioters operate. Here, various challenges against political rioting might arise: First, that given the democratic features of their society, they impose unnecessary harm when they resort to violent protest against the injustices they face. Second, that their use of public violence has little chance of success, as it is more likely to alienate fellow citizens and to lead to further injustices. Finally, that their deployment of spontaneous and unrestrained violence is bound to inflict misdirected, disproportionate harm. If correct, these objections can help to support the 
aforementioned common responses to political riots, which treat them as an impermissible and inexcusable resort to violence that ought not be tolerated in democratic societies.

In the following pages I will challenge these objections. I will suggest that, under circumstances that are not far from those we find in some real-world democracies, the resort to political rioting can comply with the criteria of permissible defensive harm. As we shall see, even in democratic societies spontaneous violent protest can become the only means available for oppressed citizens to secure a range of valuable political goals, the importance of which critics of rioters have perhaps underestimated. It can sometimes have a reasonable chance of success of achieving these goals; and when properly constrained the harm it inflicts on the state and on fellow citizens can be proportionate. My analysis seeks to present, then, a form of rioting that is permissible even in democratic states. In the process of identifying its features, I will refer to historical cases of public disorders. In doing that I do not intend to provide full moral assessment of actual participants in these specific cases. Rather, I aim to show that the conditions for justified rioting have been at least partially materialized in real episodes of public disorder. This demonstration shows that my proposed account of justified riots is not too far removed from the reality of riots, nor does it make demands that rioters could not possibly meet. It also shows that riots, as a real-world phenomenon, are by no means guaranteed to be impermissible in political circumstances that would be fairly familiar to many real-world citizens. This conclusion puts pressure on the typical blanket responses rioters receive from policy makers and fellow citizens. For it suggests that they are far too hasty to condemn, and 
that they are likely to be overly harsh. ${ }^{9}$

The article develops as follows. In Section 1 I provide an account of political rioting, which challenges common depictions of rioters as engaging in senseless violence.

Section 2 elaborates on the goals and aims of political rioters, highlighting the various political goods they seek to achieve. It also rejects the suggestion that - in contrast with civilly disobedient protestors - political rioters violate their democratic obligations to limit themselves to restrained political protest. The next sections turn to examine what I take to be the most powerful objection to political rioting - that it imposes impermissible harm. Section 3 focuses on the tests of success and necessity. Section 4 focuses on the test of proportionality. Section 5 explores weaker defences of political rioters, for those who remain unpersuaded by my account of justified rioting. Section 6 concludes.

\section{Political rioting: Definition and Causes}

I'll define a riot as a public disorder in which a large group of actors, acting spontaneously and without formal organization, engages in acts of lawlessness and open confrontation with law enforcement agencies. Rioters typically inflict various types of harm in the course of a riot: damage to public property (e.g. to public buildings, police cars and fire engines); damage to private property (e.g. shops and cars); and harm to persons (most commonly through clashes with police officers). I will return to analyze these specific harms in Sections 3 and 4.

\footnotetext{
${ }^{9}$ I limit the discussion here to the moral assessment of rioters. But my argument has implications for the common practice of imposing especially severe punishments on rioters.
} 
Political scientists, sociologists and historians have paid ample attention to the causes of riots. ${ }^{10}$ Early commentators, most famously the $19^{\text {th }}$ century French sociologist Gustave Le Bon, suggested that riots are caused by a "crowd mentality" that takes over a mob, its members losing "their conscious personality and revert[ing] to a primitive racial unconscious which accounts for the barbarism of crowd action". ${ }^{11}$ Others depicted rioters as criminals, gang members and "riff-raff", who seize on an opportunity to behave in a socially deviant way, or that they engage in rioting "for fun and profit". ${ }^{12}$ Indeed, rioters are often depicted by public authorities as engaging in senseless or opportunistic violence. ${ }^{13}$ But more recent studies challenge such theories. One widely accepted model of riots, developed by the criminologist David Waddington, offers a multi-variant explanation for the eruption of riots. ${ }^{14}$ In contrast with earlier analyses, Waddington shows that riots are often a response of a disadvantaged group to shared experiences of "subjective deprivation, social exclusion, political powerlessness and moral outrage". ${ }^{15}$

\footnotetext{
${ }^{10}$ For general reviews of that literature see David Waddington, "Riots", in The Oxford Handbook of Social Movements ed. D Della Porta and M Diani (Oxford: oxford University Press, 2016). Steven Wilkinson, "Riots" Annual Review of Political Science 12 (2009), 329-43.

${ }^{11}$ Stephen D Reicher, "The St. Pauls' Riot: An Explanation of the Limits of Crowd Action in Terms of a Social Identity Model", European Journal of Social Psychology 14, 1 (1984), 2.

${ }^{12}$ E.g. Edward C Banfield, The Unheavenly City Revisited ( Boston: Little Brown, 1974), 211-233.

${ }^{13}$ E.g. The UK Home Secretary David Blunkett's referral to the Bradford rioters as "maniacs" who "burnt down their own businesses". Andrew Sparrow "Blunkett Attacks 'Whining' Rioters" The Telegraph 06/9/2002.

${ }^{14}$ David Waddington, Contemporary Issues in Public Disorder: A Comparative and Historical Approach (London: Routledge, 1992). For a review of critiques of the model see Mike King, and David Waddington. "Flashpoints Revisited: A Critical Application to the Policing of Anti-Globalization Protest." Policing \& Society 15, 3 (2005), 255-82.

${ }^{15}$ David Waddington, "The Madness of the Mob? Explaining the 'Irrationality'and Destructiveness of Crowd Violence”, Sociology Compass 2, 2 (2008), 681.
} 
In what follows I shall focus on rioters who respond to severe and pervasive social injustices. Such injustices mar at least some contemporary democracies, where, despite overall levels of prosperity, portions of their populations, and often racial minorities in particular, experience serious material deprivation, social exclusion and political marginalization. The causes of such systematic injustices are complex, but it is usually possible to identify state laws and policies that contribute to and sustain them, and also on-going state failures to address and ameliorate them.

One much-discussed example of such state failure is the American urban Ghetto. Ample empirical evidence demonstrates that inner city Ghettos, overwhelmingly populated by African-Americans, were created by state policies of racial segregation, and maintained through a "legacy of state-sponsored antiblack racial discrimination". ${ }^{16}$ These policies locked entire racial communities in urban spaces of poverty and isolation. Low-quality of public education, combined with the physical isolation caused by lack of public transportation facilities, undermines their access to the labor market. ${ }^{17}$ The few jobs that are accessible are hard, low-skilled, often dangerous, and pay neither a living wage nor offer advancement. ${ }^{18}$ Lack of viable

\footnotetext{
${ }^{16}$ Elizabeth Anderson, The Imperative of Integration (Princeton: Princeton University Press, 2010), 69. Key works on the development of the inner-city Ghetto and the deprivations it leads to include Douglas Massey and Nancy Denton, American Apartheid: Segregation and the Making of the Underclass (Cambridge Mass.: Harvard University Press, 1993). Shelby, Dark Ghettos: Injustice, Dissent, and Reform. William Julius Wilson The Truly Disadvtnaged (Chicago: The University of Chicago Press, 1987).

${ }^{17}$ Kathryn Neckerman, Schools Betrayed: Roots of Failure in Inner-City Education (Chicago: University of Chicago Press, 2008).

${ }^{18}$ William Julius Wilson, (2011) When Work Disappears: The World of the New Urban Poor, New York, Vintage, chapter 1. Shelby, Dark Ghetto, chapter 6.
} 
work opportunities then leads to "unrivalled concentrations of poverty", ${ }^{19}$ to dependence on welfare, and pushes young people to lucrative criminal opportunities, including drug trafficking. ${ }^{20}$ These generate high levels of crime-related violence, which are further exacerbated by poor state investment in police services and in law enforcement mechanisms specifically in black neighborhoods. ${ }^{21}$ All these contribute to the physical decay of the neighborhood, which is exacerbated by governmental disinvestment and neglect. ${ }^{22}$ The lack of personal safety, of access to adequate medical services, to nutritious food and to public play and leisure spaces, has dire impact on the physical and mental health of Ghetto residents. ${ }^{23}$ Finally, and adding to the pathological relationship between the state and such these communities, is their racially-biased treatment by American law enforcement authorities, which includes racial profiling, police harassment and police violence, ${ }^{24}$ and by the American criminal justice system, which generates unprecedented incarceration rates amongst black Americans, to the extent that prison time has now become "a normal stopping point on the route to midlife" amongst American black male high school dropouts. ${ }^{25}$ As Shelby suggests, any reasonable conceptions of justice should recognize that

\footnotetext{
${ }^{19}$ Massey and Denton, American Apartheid, 9.

${ }^{20}$ Elijah Anderson, Code of the Street: Decency, Violence, and the Moral Life of the Inner City (New York: Norton, 1999). Jeffrey Fagan and Deanna L. Wilkinson, "Guns, youth violence, and social identity in inner cities," in Michael Tonry and Mark H. Moore (eds.) Crime and Justice, 24 (Chicago: University of Chicago Press) 104188.

21 Alexandra Natapoff, 'Underenforcement' Fordham Law Review 75, 3, (2006) 1715-1776. Anderson, The Imperative of Integration, 41-44.

${ }^{22}$ Massey and Denton, American Apartheid, 132-137.

${ }^{23}$ Aaron Curry, Carl Latkin, and Melissa Davey-Rothwell, "Pathways to Depression: The Impact of Neighborhood Violent Crime on Inner-City Residents in Baltimore, Maryland, USA", Social Science \& Medicine 67, 1 (2008). William Goldsmith and Edward Blakely, Separate Societies (Temple University Press 2010), chapter 2. ${ }^{24}$ Randall Kennedy, Race Crime and the Law (New Your: Vitnage Books, 1998). ${ }^{25}$ Becky Petit and Bruce Western, "Mass Imprisonment and the Life Course: Race and Class Inequality in U.S. Incarceration", American sociological review 69, 2 (2004), 164. Michael Tonrey, Malign Neglect: Race, Crime and Punishment in America (Oxford: Oxford University Press, 1995).
} 
policies and processes that lead to these devastating outcomes constitute pervasive, gross violations of fair social cooperation. ${ }^{26}$ The political riots I will focus on here, then, are responses to injustices of this type and scale.

The second core feature of political rioting is that it is a form of political protest. Rather than a display of maddened violence, the political riot is a communicative episode - its participants intending to deliver a message to the police, the government, and to fellow citizens. As we shall see in greater detail in the next Section, political rioters communicate various messages to these audiences: anger and condemnation of the injustice, a demand for a change of public policy, and a message of defiance of the legal order. Such messages are expressed through the open confrontational engagement in destructive acts, accompanied by shouts like "Don’t Shoot!" (a reference to police violence), "Fuck the System!" and "Fuck the Police!". ${ }^{27}$

Not all real world riots, and certainly not all real world rioters, are political in the way I defined. ${ }^{28}$ Nevertheless, empirical evidence suggests that political rioting is not uncommon in real-world democracies. Salient examples include the urban Ghetto riots that swept over the US throughout the 1960s. As the 1968 US National Advisory

\footnotetext{
${ }^{26}$ Shelby, Dark Ghettos: Injustice, Dissent, and Reform. Cf. Anderson, The Imperative of Integration, chapter 4. Young, Justice and the Politics of Difference, chapter 2. Such problems are not unique to the US. See for example Craig Browne and J McGill (eds.) Violence in France and Australia (Sydney: Sydney University Press, 2010). Loïc Wacquant, "The Rise of Advanced Marginality: Notes on Its Nature and Implications", Acta Sociologica 39, 2 (1996).

${ }^{27}$ I use the term "communicative" in a broad sense. In her recent defence of civil disobedience Kimberley Brownlee uses a narrower definition of communicative protest, which includes, inter alia, the commitment to engage in a respectful and reasoned deliberation (Kimberley Brownlee, Conscience and Conviction: The Case for Civil Disobedience (Oxford: Oxford University Press, 2012), 42-46). I shall return to discuss such restrictions in Section 2.

${ }^{28}$ Gary T Marx, "Issueless Riots", The Annals of the American Academy of Political and Social Science 391, 1 (1970).
} 
Commission on Civil Disorders' report (the "Kerner Report") concluded, these riots were a response to the pervasive racial segregation in the US at the time, the violent and discriminatory treatment of African American citizens by the police, and the widespread social and economic deprivation in inner-city Ghettos, which the Civil Rights Movement, despite its various political successes, was unable to reform. ${ }^{29}$ The riots that spread across France in 2005 were also a response to pervasive and persisting racial marginalization, economic deprivation, and racially-targeted police violence. ${ }^{30}$ Some argue similarly for the 2011 English riots. As one report based on dozens of interviews with participants concluded, "at the heart of what the rioters talked about was a pervasive sense of injustice", including poverty, unemployment and social inequality, a sense of exclusion, of lack of social worth and hopelessness. ${ }^{31}$ These findings suggest that political rioting is a real political phenomenon, worthy of moral assessment in light of its political nature. ${ }^{32}$

${ }^{29}$ Report of The United States National Advisory Commission on Civil Disorders (Washington DC: US Government Publishing Office, 1968). Cf. Robert M Fogelson, "Violence and Grievances: Reflections on the 1960s Riots", Journal of social issues 26, 1 (1970). James A. Button, Black Violence (Princeton: Princeton University Press, 1978). Kevin Mumford, Newark: A History of Race Rights, and Riots in America (New Yourk: New York University Press 2007).

${ }^{30}$ Craig Bronwe and Phillipe Mar, "Enhancing Self-Poitions: Creative Disrespect in the 2005 French Riots", in C. Browne and J McGill (eds.) Violence in France and Australia. Cathy Schneider, Police Power and Race Riots: Urban Unrest in Paris and New York (Philadelphia: University of Pennsylvania Press, 2015), chapter 4. Schneider focuses on police behavior as the igniting factor of these riots. ${ }^{31}$ Paul Lewis et al., Reading the Riots: Investigating England's Summer of Disorder (The Guardian and London School of Economics, 2011), 14. Cf. Daniel Briggs, "What We Did When It Happened: A Timeline Analysis of the Social Disorder in London", Safer Communities 11, 1 (2012). Tim Newburn et al., "“The Best Three Days of My Life': Pleasure, Power and Alienation in the 2011 Riots", Crime, Media, Culture 14, 1 (2018).

${ }^{32}$ Some activists prefer the term "uprisings" to describe social disorders that bear the features I described. Given that the term "riots" is commonly used both in political practice and in the sociological literature, I shall continue to use it in a non-pejorative sense. 


\section{Political rioting - goals and aims}

In order to assess the permissibility of political riots, I now turn to examine in more detail their participants' goals and aims. In doing so, I take the lead from common defenses of civil disobedience - also a public, communicative and illegal protest. It is a common view that, despite its illegality, civil disobedience can be justified if it is carried out on behalf of sufficiently important political causes. As I will now show, political rioters act in the service of goals that are similar to those of civilly disobedient protestors. But there are also important differences between these two forms of protest, which cast doubt on the permissibility of political rioting in democratic societies.

The first goal sought by political rioters, and one they share with civilly disobedient protestors, is to bring about a change of public policy that will eradicate, or in the least ameliorate, the substantive violations of justice they experience at the hands of the state. ${ }^{33}$ The tactic they choose - public destructive protest - resists the injustice in two correlated ways. First, the use of "shock tactics", such as open confrontation with the police, draws public attention to their plight. ${ }^{34}$ Second, given the various costs that disruptive violence entails for the state and society, its use can wrestle concessions from policymakers. As Malcolm X famously observed: "If the white people realize what the alternative is, perhaps they will be more willing to hear Dr. King", 35

\footnotetext{
${ }^{33}$ John Rawls, A Theory of Justice, 2nd ed. (Cambridge, Mass.: Belknap Press of Harvard University Press, 1999), 326-31, 335-43.

${ }^{34}$ I borrow that term from Mathew Humphrey and Marc Stears, "Animal Rights Protest and the Challenge to Deliberative Democracy", Economy and Society 35, 3 (2006), 411.

${ }^{35}$ Quoted in James Balwdin, "Malcolm X and Martin Luther King: What They Thought About Each Other", Islamic Studies 25, 4 (1986), 398. For an analysis of
} 
A second important goal of political rioters is to resist their political marginalization. Here too they resemble civilly disobedient protestors, who, at least according to some accounts, are justified when they simply challenge hegemonic discourses and bring to the fore marginalized voices. ${ }^{36}$ Rioters can play a similar role: it is a familiar phenomenon in democratic societies marred by severe social and racial inequalities that the disadvantaged and oppressed are rendered "invisible" in the public sphere their voices and interests absent from the political discussion and from major media outlets. ${ }^{37}$ By using extraordinary tactics of violence and defiance, rioters resist such unjust marginalization, and gain public presence - on the television screen, in newspapers and commission reports. Indeed, rioters often explain their actions as an attempt to get the political presence that is denied from them by "normal politics". For example, Waddington reports that participants in the 2005 Banlieue riots testified that they burn cars "because the cameras like [flaming vehicles]" and "it's the only way to make ourselves heard". ${ }^{38}$ Similarly, the American historian Robert Fogelson reports that participants in the race riots of the 1960s shared a sense of accomplishment that "was not derived from a profound passion for destruction [...] but rather from a singularly successful attempt at communication $[\ldots]$ This time white society did pay

state's accommodating responses to riots see Erik Bleich, Carolina Caeiro, and Sarah Luehrman, "State Responses to 'Ethnic Riots' in Liberal Democracies: Evidence from Western Europe", European Political Science Review 2, 2 (2010).

${ }^{36}$ David Lefkowitz, "On a Moral Right to Civil Disobedience", Ethics 117, 2 (2007). Daniel Markovits, "Democratic Disobedience", Yale Law Journal 114 (2005), William Smith, "Civil Disobedience and the Public Sphere", Journal of Political Philosophy 19, 2 (2011).

${ }^{37}$ Young, Justice and the Politics of Difference (Princeton: Princeton Universtiy Press, 1990), 39-65.

${ }^{38}$ Waddington, “The Madness of the Mob?”, 685. 
attention". 39

Finally, through the resort to public acts of destruction and open confrontation with the police, rioters communicate anger towards the state and defiance of its political authority. ${ }^{40}$ Here rioters are clearly distinct from civilly disobedient protestors. It is often argued that civil disobedience - despite its illegality - expresses a fundamental respect of the authority of the state. ${ }^{41}$ This respect is communicated through protestors' commitment to non-violent protest and their submission to arrest. In contrast, political rioters conceal their faces, verbally abuse the police, flee and clash with them. They are, to use Jennet Kirkpatrick's helpful terminology, “uncivilly disobedient": violent, disrespectful and defiant. ${ }^{42}$

This fundamental difference between civil disobedience and political rioting offers one reason for the common rejection of riots as an impermissible form of protest in democratic societies. According to this objection, such societies operate as reciprocal,

\footnotetext{
${ }^{39}$ Fogelson, "Violence and Grievances", 146. According to the political scientist James Button many federal executives and local administrators saw the urban disturbances of the 1960s as a form of direct political participation of groups that were subjected to racial, social and political exclusion. Button, Black Violence, 173. ${ }^{40}$ Edward Ransford, "Isolation, Powerlessness, and Violence: A Study of Attitudes and Participation in the Watts Riot", American Journal of Sociology 73, 5 (1968). Schneider, Police Power, 186.

${ }^{41}$ e.g. Hugo Adam Bedau, "Civil Disobedience and Personal Responsibility for Injustice", in H. A. Bedau (ed.) Civil Disobedience in Focus, (London: Ruotledge, 1991), 51. David Lefkowitz, 'On a Moral Right to Civil Disobedience ', John Rawls, $A$ Theory of Justice, 322. Not everyone accepts non-violence and respect for the law as core features of civil disobedience (e.g. Kimberley Brownlee, 'Features of a Paradigm Case of Civil Disobedience', Res Publica 10, 4 (2004). David Lyons, 'Moral Judgment, Historical Reality, and Civil Disobedience', Philosophy and Public Affairs 27, 1 (1998). But even those who opt for a broader definition of civil disobedience do not attempt to systematically defend it as an essentially violent and defiant form of protest.

42 Jennet Kirkpatrick, Uncivil Disobedience: Studies in Violence and Democratic Politics (Princeton Princeton University Press, 2008), 14-15.
} 
cooperative ventures of mutual co-operation. Their citizens' ensuing political duties include respecting the authority of the state or limiting themselves to civil, dialogic political communication that abides by the rules of the democratic game. Civilly disobedient protestors, who limit themselves to non-violent (or at most limited, symbolically-violent) persuasive modes of communication, comply with these requirements. ${ }^{43}$ Political rioters - angry, violent and defiant - do not.

But in response we should note that defenses of civil disobedience that include these restrictions typically focus on a political context that is quite different from the one I described. Rawls, for example, famously limits his defense to "nearly just societies", which, at the minimum, endorse adequate standards of justice, and where "in the long run the burden of injustice [is] more or less evenly distributed over different groups within society." 44 Similarly, democratic defenses of civil disobedience analyze it in the context of well-functioning democracies, which suffer from occasional inertias and imbalances of political power. ${ }^{45}$ Perhaps the limits of permissible protest should be drawn at civil disobedience in such societies. ${ }^{46}$ But the political rioters I defend act in different political circumstances, characterized by much more serious and systematic injustices. Under such conditions the restrictions that defenders of civil

\footnotetext{
${ }^{43}$ Rawls, A Theory of Justice, 320, 336-37. Lefkowitz, 'On a Moral Right to Civil Disobedience ', 216. Cf. Kimberley Brownlee, Conscience and Conviction, 20-24, 2946.

${ }^{44}$ Rawls, A Theory of Justice 312.

${ }^{45}$ Markovits, "Democratic Disobedience", Smith, "Civil Disobedience and the Public Sphere".

${ }^{46}$ Rawls briefly mentions the possibility that, if the civilly disobedient appeal fails, "forceful resistance may later be entertained" (Rawls, A Theory of Justice, 321-22). But he does not explore the specific circumstances where that may happen (Ibid., 323), It is a further question, which I don't have the scope to address here, whether on his view these circumstances could ever arise in a nearly just society.
} 
disobedience advocate may well become superfluous. ${ }^{47}$ Consider first rioters' resort to coercive measures. I believe that, as with justified civilly disobedient protestors, justified political rioters should remain fundamentally committed to the realization of the democratic ideal. In the circumstances Rawls describes this commitment would prohibit a minority from coercing a majority to submit to its demands. But when the democratic process itself becomes systematically marred by political marginalization, which results, inter alia from ongoing material deprivation, and social and cultural exclusion, rioters can plausibly argue that their use of violent, coercive measures is itself is a form of effective democratic participation, and that when it helps to correct those background injustices, in the long-run it further serves democracy (and justice). ${ }^{48}$

What about the expression of defiance and disrespect? Are those incompatible with democratic citizens' political obligations? I take it that the answer to this question depends on the nature of the political authority to which they respond. Some democratic states, although marred by oppressive and unjust practices, demonstrate an earnest will to correct these failings, which would indicate a basic level of respect for all their citizens. The response to the injustices they commit ought to be constrained

${ }^{47}$ Cf. Robert Jubb "Disaggregating Political Authority: What's Wrong with Rawlsian Civil Disobedience?" Political Studies (forthcoming). Rawls mentions that his account of civil disobedience may not fit such societies ((Rawls, A Theory of Justice, 339).

${ }^{48}$ The commitment to the democratic ideal implies then that justified rioters may protest only against injustices that should be recognized as serious violations of justice from the standpoint of all reasonable conceptions of justice (and I take it for granted that the type of violations I described earlier fall under this description). Notice that this restriction does not similarly apply to civil disobedience: here, because protestors seek to persuade rather than coerce the majority, they may resort to this form of protest even against policies which only their (reasonable) conception of justice deems as seriously unjust (an example might be the case of abortion. Jonathan Quong, Liberalism without Perfection (Oxford: Oxford University Press, 2011), 197). 
by these considerations, perhaps in the way that Rawls and others suggest. But other states fail to meet this standard, and their reluctance to bring about change expresses gross disrespect to sections of their population. As Shelby forcefully argues, if the terms of fair social cooperation are broken in this way, in the least those who are oppressed by the state are not under an obligation to demonstrate respect of its authority. $^{49}$

Furthermore, under such conditions of serious injustice the communication of anger and defiance can become a valuable political goal in itself. In the first instance, anger and defiance are simply apt moral responses to the state - as the corporate moral agent whose policies contribute to and/or blatantly fail to address the pervasive social and racial injustices that blight the lives of some of its citizens. ${ }^{50}$ As Amia Srinivasan suggests, expressing them has a non-instrumental value for the victims of injustice. ${ }^{51}$ They are also intrinsically important in that they force an unaccountable agent, who acts wrongly and refuses to acknowledge their wrongdoing, to face the consequences of their actions. ${ }^{52}$ And the public expression of anger and defiance also has important

\footnotetext{
${ }^{49}$ Shelby, Dark Ghettos chapter 6.

${ }^{50}$ The view that the state itself is a corporate moral agent, of which we can have moral expectations and respond to with reactive attitudes, is fairly common in recent literature, and I shall take it for granted here. For explorations of this idea see Toni Erskine, "Assigning Responsibilities to Institutional Moral Agents: The Case of States and Quasi States", Ethics and International Affairs 15, 1 (2001). Robert Goodin, Utilitarianism as a Public Philosophy (Cambridge: Cambridge University Press, 1995), chapter 2. Anna Stilz "Collective Responsibility and the State" Journal of Political Philosophy 19, 2 (2011). For other accounts that attribute blame to states in light of their gross injustices see Jeffery Howard, "Moral Subversion and Structural Entrapment", Journal of Political Philosophy 26, 1 (2016). Victor Tadros, "Poverty and Criminal Responsibility”, The Journal of Value Inquiry 43, 3 (2009).

${ }^{51}$ Amia Srinivasan, "The Aptness of Anger”, Journal of Political Philosophy 26, 2 (2018).

52 This does not mean, as Martha Nussbaum has suggested, that anger involves a retributive desire to down-rank its object and impose suffering on him, and is therefore incompatible with public reason (Martha Nussbaum, Anger and
} 
instrumental functions: being confronted by these emotional responses offers a powerful way for audiences to "recognize and understand injustices when they would otherwise have struggled to do so", thus promoting the rioters' attempt to generate a change of policy. ${ }^{53}$ And it serves important functions for the oppressed themselves. As Waddington notes, the very act of defiance provides participants an opportunity to "say and do something that [is] ordinarily denied by unsympathetic and unyielding political systems." 54 To experience freedom from domination and political marginalization in this way - even for a short period - is a valuable experience for people who in their everyday life are routinely harassed and threatened by their state. ${ }^{55}$ Taking part in an act of collective defiance can also give participants and their community a sense of empowerment and self-respect, as they assert themselves as agents who are not cowed by oppression. And realizing that other people share your anger can serve as a powerful motivation to act for change, a countermeasure against the sense of powerlessness that typically accompanies oppression. ${ }^{56.57}$

Forgiveness: Resentment, Generosity, Justice (Oxford: Oxford University Press, 2016), pp. 20-22). As Srinivasan points out, anger often involves the mere desire that its object bears the (proportionate) pain involved in recognizing their wrongdoing, and as such can be an apt public response.

${ }^{53}$ Maxime Lepoutre, "Rage inside the Machine: Defending the Place of Anger in Democratic Speech", Politics, Philosophy \& Economics (2018), 14.

${ }^{54}$ Waddington, Contemporary Issues in Public Disorder: A Comparative and Historical Approach, 25. cf. Newburn et al., "“The Best Three Days".

${ }^{55}$ On the harm of domination see Philip Pettit, Republicanism: A Theory of Freedom and Government (Oxford: Clarendon Press, 1997).

${ }^{56}$ Audre Lorde, “The Uses of Anger”, Women's Studies Quarterly 25, 1/2 (1997). There is empirical evidence to support this claim: the sociologist Cathy Schneider points out that American activists who had "cut their teeth" on riots of the 1960s later formed black and Puerto Rican power movements (Schneider, Police Power 29-30). ${ }^{57}$ Some argue that the oppressed have a prima facie duty to resist their own oppression, as a way of protecting their moral agency and self-respect (e.g. Bernard Boxill, "Self-Respect and Protest", Philosophy \& Public Affairs 6, 1 (1976).) While I find these claims plausible, I don't think the oppressed must discharge this duty necessarily through the engagement in the collective and open defiance of their state, given the particularly high costs rioting can entail for participants. 
To conclude, the claim that political rioting (as opposed to civil disobedience) is incompatible with democratic citizens' political obligations rings hollow in democracies marred by serious injustices. And yet, the juxtaposition of rioting and civil disobedience highlights a more challenging set of objections to political riots. After all, as Shelby points out, even conditions of serious social and racial injustice do not cancel out oppressed citizens' natural duties, including the duty not to inflict unjustified harm on others. ${ }^{58}$ The most serious challenge rioters face, then, is that while their political goals may be worthy, the resort to violence (rather than peaceful protest) in order to attain them violates this natural duty. In order to determine whether there exists a form of political rioting that can avoid this charge, we need to turn to existing standards of permissible defensive harm. For as we saw throughout this Section, political rioting has clear defensive goals, as its participants aim to undo, or in the least ameliorate, the conditions of injustice they experience, and to resist their political marginalization. It follows, then, that the permissibility of their actions should be assessed in light of the constraints offered by ethicists of self-defense and war - success, necessity and proportionality. ${ }^{59}$

\section{Success and Necessity}

It is a familiar requirement that the use of defensive violence is permissible only if it

\footnotetext{
${ }^{58}$ Shelby, Dark Ghettos 219.

${ }^{59}$ In the discussion that follows, and for simplicity of exposition sake, I treat these three conditions as independent of each other, and discuss them separately. However, it should be noted that there are ongoing debates in contemporary just war theory on the conceptual relation between the three, and several authors point to various dependencies between them. For the purposes of discussion here I put these issues to the side. Clearly, all three conditions matter for the moral assessment of riots. Whichever conceptual relation between them one opts for will affect the structure of the analysis, but not the core conclusions I draw.
} 
has a reasonable prospect to avert, or in the least ameliorate the attack that triggered it. It is fairly clear how rioters' shock tactics have a reasonable prospect at garnering public attention and communicating anger and defiance - both of which, as we saw, serve rioters in important ways. However, do these tactics have a reasonable prospect of generating positive policy changes that will improve oppressed citizens' material deprivation and social exclusion? Some evidence might seem to offer a negative answer to this question. For example, the Ghetto riots of late 1960s were met with a backlash of public opinion and repressive policies to restore law and order. ${ }^{60}$ Similarly, the English rioters of 2011 did not have a perceptible effect on government spending on poverty reduction in the affected communities. On the contrary, as we saw in the Introduction, they were met with public fear and resentment.

Perhaps it can be argued that the success condition is fulfilled even if rioters do not have a reasonable prospect of achieving all their goals. Perhaps it would be enough, for example, if they have a reasonable prospect of resisting political marginalization and communicating anger and defiance, thus maintaining a sense of self-respect and pride. Some accounts of permissible defensive harm would support this conclusion, as they suggest that victims of aggression can be justified in inflicting harm on their aggressors even when doing so would have no chance of mitigating the original attack, if through their actions they demonstrate that they are not "just passive objects to be trodden upon". ${ }^{61}$ But this position strikes many as controversial, and anyway will be even less persuasive if the rioters would in fact worsen the condition of fellow

${ }^{60}$ Michael W Flamm, Law and Order: Street Crime, Civil Unrest, and the Crisis of Liberalism in the 1960s (New York: Columbia University Press, 2007).

${ }^{61}$ Daniel Statman, "On the Success Condition for Legitimate Self-Defense", Ethics 118, 4 (2008), 669. Cf. Helen Frowe, Defensive Killing (Oxford: Oxford University Press, 2014), 109-115. 
oppressed citizens. ${ }^{62}$

However, we should not be too quick to conclude that riots never have a reasonable chance at changing public policy in real-world democracies. For there is empirical evidence to suggest that it is not that uncommon for governments to respond with highly or moderately accommodating measures to riots. ${ }^{63}$ High accommodation involves measures such as public recognition of the underlying causes of the riots, substantial increases in the allocation of financial resources to welfare programs, and legal measures to address discrimination and institutional racial biases. There are studies that suggest that some historical riots had such an effect. For example, the race riots of the early 1960s in the US, led to the famous Kerner Report, with its oft-cited recognition that "our nation is moving toward two societies, one black, one white separate and unequal,"64 which recommended "a massive and sustained commitment to action" to end poverty and racial discrimination; ${ }^{65}$ and they had a substantive impact on federal aid programs to inner city populations. ${ }^{66}$ Medium level accommodations make less significant, but still tangible policy changes. They involve

${ }^{62}$ For critique of the honor-based defense see David Rodin "Justifying Harm", Ethics 122, 1 (2011) , 92-93.

${ }^{63}$ For general review and comparative study see Bleich, Caeiro, and Luehrman, "State Responses" 280 . Of the four cases this study analyses, three riots generated a medium accommodating response, and one generated a high accommodating response.

${ }^{64}$ Summary of Report, The National Advisory Commission on Civil Disorders (US Government Printing Office, 1968).

${ }^{65}$ Frances Fox Piven and Richard A Cloward, Poor People's Movements: Why They Succeed, How They Fail, vol. 697 (New York: Pantheon Books, 1979), 273.

${ }^{66}$ Button, Black Violence. Richard Fording, "The Conditional Effect of Violence as a Political Tactic: Mass Insurgency, Welfare Generosity, and Electoral Context in the American States", American Journal of Political Science 41, 1 (1997). Alexander Hicks and Duane H Swank, "Civil Disorder, Relief Mobilization, and AFDC Caseloads: A Reexamination of the Piven and Cloward Thesis", American Journal of Political Science (1983). Another case, discussed in Bleich, Caeiro, and Luehrman, "State Responses" is the Lyon Riots of 1990, which led to significant legal and financial measures to tackle the social and economic marginalization of racial minorities in France. 
measures such as the allocation of hundreds of millions of dollars to welfare programs, institutional mechanisms to improve community-police relations and more limited declarations of support for the rioter's cause. ${ }^{67}$ An example here might be the English race riots of the early 1980s, which generated the sympathetic Scarman Report and an increase in government spending on poverty and unemployment in cities where the riots occurred. ${ }^{68}$ Based on these and similar findings, political scientists offer various models for the likely impact of riots, focusing on factors such as the agenda and electoral incentives of the government in power or the relative waning of the impact of violence over time (where violence is more likely to have a positive impact in its earlier stages). ${ }^{69}$

Most ethicists of self-defense use an evidence-based standard of the success condition, which suggests that it should be based on the conclusion that a rational and unbiased person would draw from the evidence that is reasonably available to her. ${ }^{70}$ Clearly, on this standard the decision to riot can be unjustified given the very low prospects of its success in bringing about a positive policy change. For example, if

${ }^{67}$ Bleich, Caeiro, and Luehrman, "State Responses" 273-274.

${ }^{68}$ Ibid., 278-281. Peter John, "Explaining Policy Change: The Impact of the Media, Public Opinion and Political Violence on Urban Budgets in England", Journal of European Public Policy 13, 7 (2006). Bleich et. al. offer another important insight for the current discussion. In two of the cases they analyze, the state responded accommodatingly to the rioters' cause, but at the same time deployed highly repressive means against the rioters themselves, including increased legal penalties. This finding implies that the presence of harsh responses to rioters (which are the subject of my critique here) does not rule out the possibility that their actions would have a positive effect on policy. My point remains that, given the intended positive effect of riots, such responses are not appropriate.

${ }^{69}$ For reviews see Bleich, Caeiro, and Luehrman, "State Responses". Hicks and Swank, "Civil Disorder, Relief Mobilization, and AFDC Caseloads".

${ }^{70}$ Frances Harbour, "Reasonable Probability of Success as a Moral Criterion in Western Just War Tradition” Journal of Military Ethics 10, 3 (2011), p. 231. Fernando R Tesón and Bas Van der Vossen, Debating Humanitarian Intervention: Should We Try to Save Strangers? (Oxford Oxford University Press, 2017), chapter 10 . 
rioting against a government that was recently elected on a platform that is hostile to the rioters cause (as was the case in the 2011 English riots); or where recent episodes of public disorder have already had a negative effect on their portrayal in the media (as was arguably the case with the late 1960 American Race Riots). But they also suggest that there are circumstances in real-world democratic societies where riots lead to a significant positive policy change. It follows then that it could in fact be reasonable for ordinary citizens to conclude that the use of spontaneous and destructive collective protest will have a sufficiently high prospect of igniting political change, or at least to bring about some moderate yet important benefits.

The second standard of permissible defensive harm, that of necessity, permits it only if it risks imposing the least morally weighted harm of all the available alternatives that can be deployed in order to deter an unjustified attack. ${ }^{71}$ Based on this standard one might insist that at least in democratic societies, citizens can use peaceable alternatives to disruptive violence in order to achieve their various goals: e.g. voting, joining a political party or taking part in more conventional modes of protest.

However, this claim underestimates the debilitating impact of pervasive socioeconomic and racial injustices. Consider first rioters' attempts to bring about political change and to resist their democratic marginalization. Empirical evidence suggests that conditions of severe structural oppression and deprivation make it extremely difficult for marginalized citizens to voice their concerns through standard channels of democratic political participation. Existing political parties do not represent them and

\footnotetext{
${ }^{71}$ Morally weighted defensive harm takes into account the level of moral protection the target has against the attack, given her own responsibility (or lack thereof) for the original harm. (Seth Lazar, "Necessity in Self Defense and War", Philosophy \& Public Affairs 40, 1 (2012), 6-7).
} 
their interests. ${ }^{72}$ The options of establishing a new political party or organizing a campaign of civil disobedience, or even of conventional political protest, are all too often seriously hindered by a lack of the resources required to successfully operate in a politically hostile environment - money, skills and connections. ${ }^{73}$ Such bleak circumstances are described, for example, in one in-depth analysis of the 2005 French riots, which suggests that participants in these riots responded to a political and social system that granted police officers impunity to commit serious abuses against them but which left them no effective avenues for complaint and redress. Such riots, it concludes, are "the last resort for those who find all other paths to justice blocked."

That is not do deny that some marginalized and impoverished communities can manage to maintain effective political presence, e.g. by building on pre-existing communal infrastructures (for example, religious networks). However, evidence suggests that for some communities doing so can be very difficult indeed. Inner-city impoverishment, like that I described in Section 1, spawns social isolation and the breakdown of local community trust and solidarity, which are necessary for political organization. ${ }^{75}$ Severe and persistent impoverishment also leads to political alienation - a sense of powerlessness, or the lack of belief in one's capacity to bring about

\footnotetext{
${ }^{72}$ For a classic discussion see Sidney Verba et al., "Citizen Activity: Who Participates? What Do They Say?", American Political Science Review 87, 2 (1993).

${ }^{73}$ Michael Lipsky, "Protest in City Politics", (Chicago: Rand McNally, 1970), 167168. Cf. Massey and Denton, American Apartheid, 153-160.

${ }^{74}$ Schneider, Police Power, 4. Similarly, in their seminal study of agenda setting Roger Cobb and Charles Eldar conclude that violence is "often [deprived groups'] only weapon in the social bargaining process". Roger W Cobb and Charles D Elder, "The Politics of Agenda-Building: An Alternative Perspective for Modern Democratic Theory", The Journal of Politics 33, 4 (1971), 914. Cf. Edward Ransford, "Isolation, Powerlessness, and Violence". Mumford, Newark, 137-138.

${ }^{75}$ Robert J Sampson, Stephen W Raudenbush, and Felton Earls, "Neighborhoods and Violent Crime: A Multilevel Study of Collective Efficacy", Science 277, 5328 (1997). Wacquant, "The Rise of Advanced Marginality", 125-126. Barbara Heisler, "A Comparative Perspective on the Underclass", Theory and Society 20, 4 (1991).
} 
change via the standard channels, which further hinders the motivation to invest time and resources in conventional political activities. ${ }^{76}$ Given the de facto political exclusion of these communities, an evidence-based standard of the necessity constraint would deem this sense of powerlessness entirely reasonable for the rational and unbiased person. ${ }^{77}$ Under such grim circumstances, spontaneous disruptive protest, which requires no advance investment of resources, planning and formal organization, may become the only form of collective protest that oppressed citizens will reasonably believe is available to them. ${ }^{78}$ When that is the case, the resort to rioting complies with the necessity condition. ${ }^{79}$

\footnotetext{
${ }^{76}$ Melvin Seeman, "On the Meaning of Alienation", American Sociological Review 24, 6 (1959).

${ }^{77}$ For a defense of the evidence-based standard of necessity see Lazar, "Necessity in Self Defense and War" 7-9.

${ }^{78} \mathrm{My}$ account of permissible riots is thus more restrictive than some defenses of civil disobedience in the following sense: in the case of political riots, it must be the case that the injustice the protesters face affects their own lives in ways that render other forms of protest inaccessible to them. In light of this restriction I am reluctant to defend privileged citizens taking parts in riots on behalf of oppressed communities, as presumably such citizens have viable access to less harmful alternatives.

${ }^{79}$ In stating this I am assuming here that necessity involves comparing the expected impact only of all available defensive alternatives. This is a fairly common view of the necessity requirement (e.g. Daniel Statman, "Can Wars Be Fought Justly? The Necessity Condition Put to the Test" Journal of Moral Philosophy 8 (2011), 435-51. Suzanne Uniacke, Permissible Killing: The Self-Defence Justification of Homicide. Cambridge: Cambridge University Press, 1996), 33-34). But no all accept it. Seth Lazar, for example, argues that the set of compared options should also include that of inaction (Lazar, "Necessity in Self Defense and War", 18-22.). In other words, if the option of not rioting (and avoiding the defensive harm riots involve) proves to be less morally costly than the option of rioting (and mitigating the harm inflicted on oppressed citizens), then rioting would violate the necessity condition. In this paper I compare the outcomes of action and inaction as part of my analysis of the proportionality condition. But on Lazar's view, the conclusions I draw there, about the circumstances under which rioting is not disproportionate, ought to be incorporated into necessity calculations. Notice though that doing that will affect the structure of the analysis, but not the final conclusions I draw on the permissibility of riots.
} 
I think the same can be said about the use of collective violence to express anger and defiance. It is undeniable that agents who face serious oppression can sometimes find ways to communicate these sentiments without resorting to violence. Canonical literary works, from Ralph Ellison to Toni Morrison, has done precisely that. But these alternative routes of expression are not open to all, and typically even less so to people who live in environments that are themselves rife with violence and who regularly experience hostile confrontations with the authorities. The modes through which people learn to express their anger and defiance are very much a product of their social environment. ${ }^{80}$ The argument that more "civil" modes of communication are fully accessible to oppressed citizens who are routinely subjected to the threat of state violence may well fail to understand their lived experience.

I have argued that marginalized citizens can find themselves in circumstances where a resort to spontaneous collective violence will comply with the success and necessity conditions. However, even when spontaneous collective violence is the only available effective means left for the oppressed, rioters can deploy it in ways that will inflict various levels of harm: from damage to public property to damage to private property; and from moderate to severe bodily and even lethal harm to police officers and civilians. I now turn to examine what success and necessity tell us about the limits of permissible riotous violence in that sense. As we will see, given the typical political context in which rioters act, there is a fairly wide, but by no means unlimited, range of defensive harms they may permissibly inflict.

${ }^{80}$ Srinivasan, "The Aptness of Anger”, 139. 
I'll examine first the limits of permissible violence in light of the success condition.

As we saw, it demands that the means that rioters deploy have a reasonable prospect of generating an accommodating response from state authorities. It suggests, then, that political rioters should avoid violence that would support their public portrayal as opportunistic or maddened criminals, and instead deploy tactics that will focus public attention on their political causes. Targeting public property (especially when accompanied by the relevant verbal messages) can effectively do that, as it communicates anger with the state itself, and defiance of its own authority. In contrast, damage to privately-owned businesses, cars and homes lacks these clear symbolic meanings. While it may well garner public attention, it will also cloud the political message of the riots, and may undermine their cause.${ }^{81}$ But an important exception here concerns the property of private agents who are themselves inexcusably complicit in the injustice against which the rioters protest. Consider the following example, drawn from the 1967 Newark Ghetto Riots. In the course of these riots protesters targeted phone booths in the Ghetto (which were owned by a private phone company). These were not acts of senseless violence. They were informed by an earlier direct action campaign by the Congress of Racial Equality (CORE) against the phone company's racially discriminatory practices. ${ }^{82}$ Damaging the property of such companies communicates that it is not just the state itself but also key players in its basic structure who share blame for the injustice and ought to change accordingly, and is permissible on the success condition.

\footnotetext{
${ }^{81}$ For example, the political element of the English riots of 2011 remains an issue of controversy amongst scholars of public disorder, precisely because of the relatively high ratio of damage to shops, including looting. See Simon Winlow and Steve Hall, "A Predictably Obedient Riot: Postpolitics, Consumer Culture, and the English Riots of 2011”, Cultural Politics 8, 3 (2012).

${ }^{82}$ Mumford, Newark, 135. For other examples of discriminating violence in these riots see Fogelson, "Violence and Grievances".
} 
Finally, there is the question of harm to persons, typically inflicted through clashes with the police. Such clashes garner public attention and communicate defiance of the state and especially the police, through which the state enforces its authority (and whose problematic interactions with oppressed citizens typically play a pivotal role in igniting riots ${ }^{83}$ ). That said, it is plausible to argue that lethal and widespread severe bodily harm to police are likely to generate public anger and resentment against the rioters, to avert public attention from the injustices to which rioters respond, and to justify the use of highly repressive means against them. So, while as a matter of principle, the success condition does not rule out such harms, it suggests that in the familiar political circumstances in which rioters typically operate, lethal harm and large scale serious bodily harm is likely damage the riots' success prospect, and that justified rioters should therefore moderate their clashes with the police accordingly, and avoid such harms. ${ }^{84}$

Turning next to the necessity test, it requires that rioters use (of the range of available means that have some chance of inflicting defensive harm) the means that impose the least morally weighted defensive harm. Assuming, as I have, that rioters do not have alternative, more peaceful means by which to deliver their messages to the state, their remaining recourse is that they violently target its property or its agents. Of these two options, the necessity condition clearly requires that rioters target public property rather than persons, especially property that symbolizes the authority of the state. What this requirement entails in practice depends on the reality on the ground. But by

\footnotetext{
${ }^{83}$ Schneider, Police Power.

${ }^{84}$ Indeed, in the four cases of successful riots Bleich et.al. analyze, the riots involved some level of bodily harm to police (typically injuring hundreds), but very few if any casualties. (Bleich, Caeiro, and Luehrman, "State Responses" 278).
} 
and large, as a general rule of thumb, things like turning over empty police cars or throwing stones at empty municipal buildings could pass the necessity test, while targeting hospitals and occupied schools will not. Some harm to private interests is also needed in order to deliver the aforementioned message of condemnation of inexcusable complicity in an unjust basic structure. The necessity condition requires that these messages will be communicated via the least harmful means - again targeting the property, rather than life and limb of business owners. What that requirement translates into on the ground will, again, depend on the circumstances, but as a general rule, things like empty shops or phone booths are appropriate targets, while private homes are less likely so.

However, it is important to note that the necessity condition does not rule out inflicting bodily harm. As I already noted, given the defiant, confrontational nature of riots, clashes with the police are part and parcel of this type of protest. Indeed, riot police will try to stop rioters' violence against property, so in order to garner the necessary public attention, rioters will inevitably need to confront them. So clearly, some bodily harm to police must be risked in order for rioters to achieve their goal. That said, it seems unlikely that in real circumstances lethal or widespread severe bodily harm to police will be required in order for rioters to generate public attention, or to communicate their anger and defiance. So necessity too, while not ruling out widespread serious harm to persons, suggests that in reality, rioters should restrain the harm they inflict on police and passersby.

\section{Proportionality}


Proportionality has been extensively debated in the just war and ethics of self-defense literatures, and competing accounts identify multiple factors that ought to go into its calculation. ${ }^{85}$ Given considerations of space, I focus here only on three factors that play a dominant role in most proportionality calculations. The first is the expected magnitude of benefit the rioters will bring (or the expected magnitude of harm that will happen if they do not engage in violent protest). Second, and balanced against it, is the expected harm rioters will inflict on the victims of their violence. ${ }^{86}$ The third factor adds to these calculations the relation of the target of the defensive harm to the attack it seeks to avert. Jeff McMahan's influential account distinguishes here between "narrow" and "wide" proportionality calculations. Narrow proportionality applies to targets that are responsible for the original harm that the defensive attack aims to avert. Here it is common to think that narrow proportionality permits inflicting on responsible agents a level of defensive harm that is at least commensurate (or roughly equal) to the harm that it seeks to avert and some even argue that the level of defensive harm may even exceed, to some reasonable degree, that of the averted harm. ${ }^{87}$ What renders an agent responsible for harm in the relevant sense is a much-disputed question, but all participants in that debate agree that at a minimum, agents who themselves culpably pose a threat on a victim are liable to equal (and some would argue even greater) defensive harm. ${ }^{88}$ Wide proportionality

\footnotetext{
${ }^{85}$ David Rodin, for example, identifies fourteen such factors. See David Rodin, "Justifying Harm".

${ }^{86}$ Ibid. 92.

${ }^{87}$ Thomas Hurka, "Proportionality in the Morality of War" Philosophy \& Public Affairs 33, 1 (2005) 39-40, 55-56. Jeff McMahan, "What Rights May Be Defended by Means of War?" in Cécile Fabre and Seth Lazar (eds) The Morality of Defensive War, (Oxford: Oxford University Press, 2014), 18. Victor Tadros, The Ends of Harm: The Moral Foundations of Criminal Law (Oxford: Oxford University Press, 2011), 175-6. ${ }^{88}$ For review of that debate see Seth Lazar, "The Responsibility Dilemma for Killing in War: A Review Essay", Philosophy \& Public Affairs 38, 2 (2010). The culpabity
} 
concerns the defensive harm that befalls agents who are not responsible, in that relevant sense, for the original harm. Here the bar for permissible defensive is set higher than for narrow proportionality: a victim may not kill an innocent passerby in order to save her own life from a lethal attacker. That is not to deny that defensive harms to uninvolved parties could sometimes be permissible, but only as a "lesser evil" - if the benefits yielded by imposing them are very substantial in comparison to the harm they cause. ${ }^{89}$

Let's examine the implications of this general framework for the various types of defensive harm that rioters impose, starting with damage to public property (and focusing on scenarios where it already meets the necessity and success constrains). As I argued in Section 1, the state, as the agent that orchestrates the basic structure of society, shares the blame - through its actions and failures - for the severe injustices against which the rioters protest. Therefore, it is appropriate to apply the standard of narrow proportionality to it. ${ }^{90}$ This means that the state is liable to suffer a level of

standard is the most restrictive in that literature, I will use it here as it poses the greatest challenge to the claim that rioters impose proporitonate damage.

${ }^{89}$ McMahan, Killing in War, 27. Another factor that has received much attention in the literature, and which I lack the space to discuss, is the intention of the agent deploying defensive harm. Most accounts agree that intended defensive harm is weightier in proportionality calculation than unintended (but foreseen) harm. In the discussion here I put that consideration to the side, focusing almost exclusively on intended defensive harm.

${ }^{90}$ Some just war theorists, including McMahan, reject the view that groups can be corporate moral agents. However, McMahan's proportionality framework, which is sensitive to the relation of the target of defensive harm to the original attack, is not in itself in tension with the claim that the state is a corporate moral agent (TanguayRenaud, Francois. "Can States Be Corporately Liable to Attack in War?" in S.Bazargan and S. Rickless (eds), The Ethics of War: Essays, (Oxford: Oxford University Press, 2017). That said, the state is a complex corporate agent, constituted of both sub-units and of individuals members. Narrow proportionality requires that when we consider a proportionate response to its wrongdoing, we must take into account the impact of that response on these units and individuals, in light of their relation to the original attack. I discuss these complexities later on in this section. 
defensive harm that does not exceed the expected benefits of the protest. As we saw earlier, if the riot generates what I referred to as 'high-level' accommodating policies, there will be substantive benefits for many oppressed citizens: the symbolic value of political attention to their cause and of the public recognition of the circumstances they face, the introduction of legal measures to address the injustice, and the investment of significant sums of money in urban regeneration and employment plans, to give a few examples. Even riots that achieve only what I referred to as 'medium-level' accommodating policies will generate important benefits, such as substantive investments in youth training and urban regeneration, investments in improving community-police relations and public recognition of the rioters' plight, as well as an opportunity to express their defiance. Against these benefits we weigh the damage that rioters will cause to the property of the state, e.g. damage to police cars, to public parks or to public buildings. This damage is not insignificant, but, given the nature of riots as typically short outbursts of spontaneous protest by a civilian population, their participants can, and often do, use fairly limited weapons (bricks, bats, sometimes firebombs) and inflict fairly limited damage. I submit that when a riot has a reasonable chance at generating high to medium level accommodating policies, limited damage to the state property is narrowly proportionate. However, there are two caveats to this conclusion.

The first caveat concerns the harm that will fall on uninvolved parties when rioters target state property. One type of such costs is the physical harm that will indiscriminately fall on vulnerable citizens if rioters target such places as hospitals, schools, or care homes. Clearly it is much harder to argue that serious harm of this type can be proportionate, even when riots have a reasonable chance of achieving 
high-level accommodating policies. Furthermore, as I already argued, rioters should reasonably predict that causing such serious harm is unlikely to meet the success or necessity conditions. So rioters ought to avoid attacking such targets.

But another type of burden, which is impossible to avoid, concerns the costs that will pass on to citizens when the state invests resources in repairing the damage rioters caused to its property (as well as in responding to the rioters' demands). In one possible scenario, the government will raise taxes to cover these expenditures, or cut the provision of less-essential public services (e.g. reduce funding for the arts, or divert resources from well-resources schools to failing ones). I think that when balanced against the substantive benefits of high and medium accommodating policies, such modest tax rises (from the prospective of each citizen), or cuts in nonessential services are widely proportionate. ${ }^{91}$ But perhaps the government will act in ways that have a more detrimental impact. For example, if the government addresses the rioters' demands by cutting the foreign aid budget, the impact on impoverished populations might be just as bad, if not worse, than the harm inflicted on oppressed citizens, and will therefore not be permitted on a wide proportionality standard. This

\footnotetext{
${ }^{91}$ In fact, it is plausible to think that these burdens should be assessed on a narrow proportionality standard, in light of citizens' level of participation in their state. Some just war theorists argue that mere participation in an unjust war (as opposed to culpability) grounds liability for lethal defensive harm (e.g. Cécile Fabre, Cosmopolitan War (Oxford: Oxford University Press, 2012). This position has been subject to critique in the context of war (e.g. Seth Lazar, "Complicity, Collectives, and Killing in War", Law and Philosophy 35, 4 (2016). However, it is far less controversial to argue that the citizens of democratic states are liable to bear at least some of the financial burdens that result from their state's own wrongdoing, given their mere participation in the state (for various developments of this argument see for example (REFERENCE REMOVED) Eric Beerbohm, In Our Name: The Ethics of Democracy (Princeton Princeton University Press, 2012). Anna Stilz, "Collective Responsibility and the State"). That literature focuses on citizens' duties to share their state's compensatory liabilities to its victims. But it can be easily extended to the duty to share the burden the state would incur when its oppressed citizens protest against its wrongdoing, in order to bring about change.
} 
is a worrying prospect. But it is also faced by any protestor against state injustices who seeks to influence budgetary decisions, including the justified civilly disobedient protestor. There is nothing special to the case of riots in that respect. I suspect that the most we can say, in response, is that ex ante, all that an evidence-based standard of proportionality can require is that rioters (as well as other protestors) should be reasonably confident that such seriously harmful consequences will not follow, given their government's track record..$^{92}$

A second caveat to damage to state property concerns the complex structure of the state, as a corporate moral agent that is constituted of many sub-units. Some of these units are corporate agents in their own right, acting under the decision and authority structures of the state (e.g. government departments and offices, police stations, schools, city councils). ${ }^{93}$ These "nested agents" are positioned in different relationships to the state and to the structural injustice it orchestrates. Some will be culpably involved (e.g. a police station that fails to root out a culture of racism), but some will not (e.g. a police station that implements effective anti-racist measures). So even when the state itself is shares blame for the injustice against which the riots protest, not all its sub-units will necessarily share the blame. ${ }^{94}$ A narrow proportionality standard that tracks blame will prohibit attacks on, say, a police station that does its best to maintain good relations with the local population. ${ }^{95}$ The requirement that rioters limit their attacks to the property of state sub-units in this

\footnotetext{
${ }^{92}$ Such considerations will also affect necessity calculations, which require the resort to the alternative that imposes the least morally-weighted harm.

${ }^{93}$ Holly Lawford-Smith Not In their Name (Oxford: Oxford University Press, forthcoming) chapter 2.

${ }^{94}$ I thank a referee for raising this point.

${ }^{95}$ As we saw in Section 3, targeting such agents is also unlikely to meet the success and necessity conditions.
} 
opens up a further objection, familiar from recent discussions in just war theory, about rioters' limited capacity to make sound judgments about their target's culpable involvement in the original wrongs. According to this objection, soldiers in the battlefield, who are not armed with "laser-guided weaponry with guilt-seeking missiles" $" 96$ cannot distinguish between culpable and innocent enemy combatants, and therefore are bound to impose disproportionate harm. But in response we should note that, unlike soldiers in the battlefield, rioters are acting in a local and a familiar environment. They will therefore have much more information about the policies and actions of the local authorities that serve them (e.g. the local police department) and should be able to adjust their actions accordingly. ${ }^{97}$

What about damage to private property? I argued that necessity and success permit inflicting harm on private agents who culpably contribute to the injustice. One example was the private companies that, due to their racist practices, were subjected to violence during the 1960 s Ghetto riots. Is damage to the property of such agents proportionate? In answering this question we need to balance, on one side of the equation, the benefits that this damage will yield for the rioters: it challenges unjust and racial practices, and pressures commercial companies, as well as the government, to acknowledge and address - legally and financially - these wrongs (e.g. through the introduction of anti-discrimination employment laws). ${ }^{98}$ On the other side of the equation, we need to consider the level of harm rioters will cause to private property.

\footnotetext{
${ }^{96}$ Seth Lazar, "Responsibility, Risk, and Killing in Self-Defense", Ethics 119, 4 (2009), 701.

${ }^{97}$ There is some evidence to suggest that in reality rioters can restrict their actions in this way. For example the French 2005 riots erupted only in locations where local authorities and police failed to develop good relationship with local residents. See Schneider, Police Power 25-31.

${ }^{98}$ Bleich, Caeiro, and Luehrman, "State Responses", 284-286.
} 
Here rioters can (and usually do) engage in violence that inflicts fairly limited harm on such companies (e.g. damaging phone booths and shop windows, or causing limited losses to inventory). Given the culpable involvement of such companies in the injustice, it is not implausible to suggest that for riots with a reasonable chance of success, such limited damage to private interests meets the narrow proportionality standard.

Do similar conclusions apply for ordinary citizens (rather than, say commercial companies)? Clearly not all citizens share the blame for the systemic injustices prevalent in their society. Some citizens are the victims rather than the perpetrators of these injustices. Others will be contributing to the social, cultural and economic processes that maintain these injustices, but many of them will be doing so simply by conducting their lives in accordance with prevalent practices and norms, often not being aware of the cumulative impact of their actions. As Iris Marion Young points out, assigning moral blame to all citizens merely in light of these accumulative and unintentional contributions is problematic. ${ }^{99}$ But we can acknowledge that view, whilst still maintaining that some ordinary citizens will behave in ways that are clearly morally reprehensible. An example might be a small shop owner who discriminates against customers of racial minorities, ${ }^{100}$ or affluent citizens who fail to do anything to resist the injustice, even when they are in a position of power to do so. ${ }^{101}$ A narrow proportionality standard that tracks blame would confirm that some

${ }^{99}$ Iris Marion Young, Responsibility for Justice (Oxford: Oxford University Press, 2011), 97-104.

${ }^{100}$ Ibid., 95.

${ }^{101}$ Young recognizes that some participants in structural injustices may act in a blameworthy manner, but insists that there are both principled and pragmatic reasons for not attributing what she calls "backward-looking responsibility" (or blame) to ordinary citizens. But even if we accept that blame is inappropriate in this context (a 
damage to the property of such individual agents is permissible (assuming, also, that it meets the success and necessity requirements). What precisely is permitted to do to such agents will depend on the their level of culpable involvement, as well as their abilities to absorb the defensive harms. ${ }^{102}$ Burning down the corner shop of a private individual when his livelihood depends on it is harm of a much greater magnitude than burning down a shop of a large chain store. The former might be liable only to a smaller level of damage on the narrow proportionality standard. Here too rioters will face the challenge of reliably distinguishing between innocent and culpable fellow citizens, and determining the latter's respective levels of liability. As before, I think the fact that rioters operate within local environment can help to address this concern. But this challenge also leads to the conclusion that targeting the properties of culpable private agents who are more able to absorb the defensive harm (such as big chain stores with racist employment practices) poses less of a risk of inflicting disproportionate harm, and that justified rioters ought to limit themselves in this way.

Finally, there is the question of violence against persons. I already pointed to the serious drawbacks that attend the deployment of lethal harm, given that it is hard to imagine a scenario in which the messages political rioters seek to deliver cannot be communicated by less harmful means, or where the use of lethal force is not likely to undermine rather than promote the political message of the riots. But given the

claim I am more reluctant to accept than Young), Young's core position that all participants in structural injustice bear a forward-looking political responsibility to resist these injustices can accommodate my view that such participants can also be expected to bear some of the costs of violent protest, if such protest is necessary to generate change. As Young suggests, what each citizens would be required to bear should be adjusted to her respective powers and capacities (Ibid., 144-145).

${ }^{102}$ For a detailed analysis of these and related factors, specifically in the context of collective wrongdoing, see Chiara Lepora and Robert Goodin, On Complicity and Compromise (Oxford: Oxford University Press, 2013), chapter 5. 
confrontational nature of riots some harm to persons is inevitable. What does proportionality tell us about its permissibility? In answering this question, we might want to apply again McMahan's distinction between narrow and wide proportionality. Undoubtedly, some police officers culpably contribute to the perpetuation of the conditions of pervasive injustice oppressed citizens in their society face. An example might be blatantly racist police officers whose treatment of citizens of racial minorities is discriminatory and sometimes brutal. ${ }^{103}$ But in reality, it is hard to see how rioters could draw such distinctions when they confront riot police. Inevitably, these clashes will harm police officers in ways that will not track blame. Can such harm be deemed proportionate?

In answering this question, I suggest we take the lead from existing accounts of permissible violence in war. Here, it is a fairly common view amongst ethicists of self-defense, and certainly amongst citizens and policy-makers, that states may resort to wide-scale lethal defensive harm not only in in response to attacks against their citizens' very lives and bodily integrity. One common view suggests that people's interest in autonomy and control over their lives permits the resort to war in order to defend their community's political self-determination. ${ }^{104}$ Relatedly, it has been argued that people's interest in autonomy and a flourishing life requires that they have access to resources necessary to develop and deploy the "personal capacities required to pursue a conception of the good" and that, when these are threatened for a very large

${ }^{103}$ See for example, the depiction of (some) French Police officers' attitudes and behavior in Schneider, Police Power chpater 4.

${ }^{104}$ Frowe, Defensive Killing, 139-143. Thomas Hurka, "Proportionality in the Morality of War" 56. David R. Mapel, "National Defence and Political Independence", in The Oxford Hanbook of Ethics of War, ed. Seth Lazar and Helen Frowe (Oxford: Oxford University Press, 2015). 
number of people, the resort to defensive war is proportionate. ${ }^{105}$ As we saw in Section 1, the harms political rioters experience at the hands of their state come quite close to this level, having a devastating impact on millions of citizens' access to decent level of education, viable employment, good mental and physical health, recreation and play, and to a minimally effective political participation. It is not implausible to suggest that a violent defensive response to such harms, which inflicts bodily harm of the scale we typically see in real world riots (namely, involving injuries in the hundreds $)^{106}$ is widely proportionate, at least if one agrees that a resort to war in order defend a population's political autonomy and flourishing lives is proportionate. $^{107}$

If this conclusion is correct (I return to consider implications if it is not in Section 5), we will have an account of what constitutes a justified riot in democratic societies: it is a riot against serious, pervasive social injustice which blocks alternative routes of effective political participation, and which occurs in political circumstances where it has a reasonable chance of success of generating a positive policy change. Its participants restrain themselves in important ways: they mainly target public property, and especially that of state units that are most clearly involved in the perpetuation of the injustice; they target also some private property, mainly that of commercial

105 Cecile Fabre "Rights, Justice and War: A Reply" Law and Philosophy 33, 3 (2014), 413. Cf. Anna Stilz, "Territorial Rights and National Defence", in The Oxford Handbook of Ethics of War ed. Seth Lazar and Helen Frowe (Oxford: Oxford University Press, 2015).

${ }^{106}$ I have in mind here, for example, the four cases described in Bleich, Caeiro, and Luehrman, "State Responses".

${ }^{107}$ As I noted in footnote 78, some accounts of necessity require a comparison between the expected impact of the chosen defensive strategy and that of inaction. When the resort to riots satisfies wide proportionality in the way I described here, it will also be the least morally-weighted costly option available to rioters in comparison with no action, and will therefore satisfy the necessity requirement in that sense as well. 
companies who culpably participate in the perpetuation of systematic injustices, and they also inflict some limited bodily harm through their direct confrontation with police.

These constraints open another important objection, which concerns the spontaneous and unstructured nature of riots. Unlike combatants in the battlefield, rioters are not organized in tight command structures, nor do they have processes for identifying and verifying targets. Given their essentially disorganized nature, the violence the rioters deploy might end up being misdirected, or get out of control. In light of this risk, the objection goes, riots remain an impermissible form of protest.

A partial reply to this concern is that in reality, the problem it identifies might not be as serious as some might think. As we saw in Section 1, there is a view of riots as outbursts of unrestrained violence, in which participants lose all sense of control. However, sociological analyses question this perception. They suggest that discriminating violence is a common feature of protest riots, and that rioters can, and often do, conform to "crowd norms" that set some limits to the level and targets of violence, including norms that prohibit targeting schools and libraries and that prohibit targeting property owned by fellow members of the relevant community. ${ }^{108}$ So although they are spontaneous and unstructured events, rioters can act with some degree of confidence that violations of crowd norms will not be that common.

And yet, clearly, crowd norms cannot prevent all forms of impermissible violence. Furthermore, given the messy reality of riots, even rioters who strive to remain within

${ }^{108}$ For evidence see Waddington, Contemporary Issues in Public Disorder 68. Cf. Fogelson, "Violence and Grievances". Reicher, "The St. Pauls' Riot" 10-11. 
the boundaries of justified harm can find it hard to limit their actions in the ways I set out. A firebomb directed at a public property might spread onto a residential building. A brick directed at a police station might end up endangering lives. And those who decide to resort to riot might also anticipate that - given the background of institutional injustice - the police force they are acting against might react with excessive force, and cause harm to fellow protestors. All these are foreseeable consequences of rioters' actions. Do they not rule out the resort to riots?

I think the answer to this question is negative, and I take the lead here, again, from common views in just war theory. It is widely acknowledged that, in the messy reality of war even just militaries will not be able to fully implement proportionality, necessity and success. Some combatants on the ground will violate orders, causing serious harm to uninvolved civilians. Others will do their best to inflict only permissible harm, and yet - given the grim reality of war - will end up causing disproportionate or unnecessary harm. Just militaries do their best to prevent these violations, but it is entirely unrealistic to assume they can be entirely eradicated. And yet few just war theorists, and even fewer policy makers, think that wars are, overall, prohibited given these foreseeable consequences. We should apply similar standards to riots. Given the unstructured and unplanned nature of riots, their participant are far less able than military commanders to gauge the impact of their own actions or to control the behavior of fellow rioters. But on the other hand the collateral harm they risk inflicting is of a different order of magnitude than that contemplated by war cabinets. War cabinets can reliably predict that even a just war fought by a disciplined army will likely kill hundreds of uninvolved civilians and injure many more. Political riots, on the other hand, have historically involved the loss of a fraction of this 
number of lives and bodily injuries. These costs are certainly not negligible, and are a cause for regret. But given that common morality allows the resort to a just war even though it is likely to inflict far more serious collateral damage, I think it would be wrong to conclude that a limited number of foreseeable, unjustified deaths and injuries renders impermissible the resort to violent protest, where such protest brings tangible relief to the millions who are oppressed by a very serious injustice. That is not to deny that wide proportionality considerations will prohibit the resort to riots if protestors should reasonably predict that the violence is likely to get entirely out of control, and that the harm to uninvolved parties is going to be more widespread. But the reality of riots suggests this need not be the case, and in practice, often is not.

\section{Excuses and Intentions}

In the previous sections I provided an account of what I take to be a justifiable riot in democratic societies. Quite likely not everyone will agree with my conclusions. Some readers might insist, for example, that given that rioters are not responding to immanent attacks to their vital interests (namely, life and bodily integrity), their resort to violence, which as we saw will likely inflict some lethal damage, remains impermissible. ${ }^{109}$ But my analysis offers important insights even for those who remain thus unpersuaded. For it suggests that they too should reject the fairly popular view that political rioters are not different from, and even worse than common criminals. The starting point for my argument here is the fact that political rioters'

\footnotetext{
109 This might follow for example from David Rodin's view that the collateral damage of war is permissible only against attackers who threaten the vital interests of a country's citizens. David Rodin, "The Myth of National Self-Defence", in The Morality of Defensive War., ed. Cécile Fabre and Seth Lazar (Oxford: Oxford University Press 2014).
} 
core motivation to is to further valid moral ends. There is an ongoing debate on the relevance of an agent's motives for the moral permissibility of her actions. One fairly dominant view argues that motives bear on the wrongness of the act itself. ${ }^{110}$ Those who adhere to this view should recognize that political rioters, who are motivated by valuable goals, are at a minimum committing a less serious wrong than opportunistic criminals, or non-political rioters. Those who deny that motives bear on the wrongness of an act should also be drawn in a similar direction. For they too should recognize that political rioters' distinct motives serve as a partial excuse for their actions, which at least renders them not as blameworthy as people who engage in destructive or harmful behavior just for self-interest, for "fun and profit" or for other unsavory ends. ${ }^{111}$ Such mitigating responses to political rioters are appropriate also in light of the fact that - as I have shown - it is so difficult to provide certain answers to many of the questions that surround the permissibility of rioting. Some of these difficulties spring from empirical complexities (e.g. determining the likely impact of violence on policy makers). Others spring from deep disagreements between reasonable people on morally difficult questions, including what might count as a proportionate violent response. The on-going disagreements on these matters, even amongst experts, should render us more careful in our response to ordinary citizens, who when confronted with similar challenges, make a judgement call some of us end up finding, in hindsight, mistaken.

${ }^{110}$ For one defence of this view see Victor Tadros, The Ends of Harm, chapter 7. For the opposing view see for example Judith Jarvis Thomson, "Physician- Assisted Suicide: Two Moral Arguments", Ethics 109, 3 (1999).

${ }^{111}$ I use the term "excuse" not in the sense of denoting lack of responsibility for the act (as for example, do defences of incapacity or duress). Rather, I use it to denote reduced culpability, or blameworthiness, for the wrongful act. See Suzanne Uniacke, Permissible Killing: The Self-Defence Justification of Homicide (Cambridge Cambridge University Press, 1996), 13-24. 
The moral assessment of political rioters gives a prominent role to their intentions and motivations. Here one might raise an epistemic challenge: how can we know what the intentions and motives of rioters are, e.g. whether they are engaging in protest, or in violent destruction "for fun and profit"? Admittedly, determining these internal facts is a difficult task; but the difficulties it raises are by no means unique to the case of political rioting. Intentions and motives routinely play a central role in determining the nature and degree of criminal wrongdoing, and criminal justice systems have come up with procedures to identify such intentions. ${ }^{112}$ Furthermore, scholars of public disorders are sensitive to this problem, and have suggested that relatively reliable evidence on rioters' intentions and motives can be gathered, by crossreferencing a variety of sources (e.g. in-depth interviews, direct observations and media and police reports). ${ }^{113}$ Sorting out the facts about the intentions and actions of specific protestors might be difficult. However, it remains the responsibility of a political community, and especially of a political community that inflicts serious injustice on some of its members, to engage in this task.

\section{Conclusions}

I argued in this article that political rioting is a unique form of political protest. I suggested that given the goals and aims of political rioting, which are highly valuable to them and to the political community as a whole, a properly constrained political riot can be justified in democracies under circumstances that are not far from the reality of many states in the world. As I emphasized throughout, I did not attempt to

112 Douglas Husak, "The Costs to Criminal Theory of Supposing That Intentions Are Irrelevant to Permissibility", Criminal Law and Philosophy 3, 1 (2009).

${ }^{113}$ David Waddington, "Waddington Versus Waddington: Public Order Theory on Trial”, Theoretical Criminology 2, 3 (1998). 
defend the actors that took part in the political riots that featured in the discussion. That said, I suspect that a further empirical investigation in light of the framework I developed here will lead to the conclusion that in some of these cases, their participants have acted permissibly, or at least had partial excuses for their behavior. Whichever specific conclusions we draw in these particular cases, the upshot of my analysis is that a political community that is quick to vilify political rioters without drawing the moral distinction between them and "common criminals", does them a further injustice. Definitive conclusions about the permissibility of each real-world riot, like each real-world war, depend on a careful assessment of the relevant empirical evidence in light of the appropriate normative standards. We cannot properly judge political rioters until we have carried out that assessment. 